Arab World English Journal (AWEJ) $2^{\text {nd }}$ Special Issue on Covid 19 Challenges January 2022 DOI: https://dx.doi.org/10.24093/awej/covid2.22

Pp.329-341

\title{
The Effects of Writing in a Class Blog on Saudi EFL Students' Attitudes towards Writing in English
}

\section{Sultan Samah A Alenezi}

School of Modern Languages and Applied Linguistics

University of Limerick, Limerick, Ireland

$\&$

Department of English and Literature

Northern Border University, Arar, Saudi Arabia

Received:9/23/2021

Accepted: 11/30/2021

Published: $1 / 24 / 2022$

\begin{abstract}
This case study aimed to explore Saudi EFL students' attitudes towards learning writing by using blogging in practicing their writing activities and tasks. It also sought to measure the effectiveness of blogging as an effective approach to enhance student's writing abilities. The participants in this study were five students second-year undergraduate EFL students studying in the Department of English in Saudi university. The participants had completed a writing skills course as a compulsory course in their study program. A semi-structured interview was used to acquire data for this case study in order to learn about learners' blogging experiences. The semistructured interview data were analyzed thematically. The findings showed that the learners' attitudes were positive toward using the class blog as a beneficial approach in EFL writing classes. Furthermore, they confirmed that their English writing skills improved as a result of blogging. Additionally, they mentioned that blogging enabled them to build an interactive learning environment in which they could share their experiences and perspectives with their peers and learn from one another. Finally, the study, emphasizes the importance of using blogging in EFL writing classes and recommends that blogging to be part of writing teaching curricula at the university level.
\end{abstract}

Keywords: Attitudes, blackboard, Blog, Saudi learners, technology, writing skills

Cite as: Alenezi, S.S.A. (2022). The Effects of Writing in a Class Blog on Saudi EFL Students' Attitudes Towards writing in English . Arab World English Journal (AWEJ) $2^{\text {nd }}$ Special Issue on Covid 19 Challenges (2) 329-341. DOI: https://dx.doi.org/10.24093/awej/covid2.22 
Arab World English Journal (AWEJ) 2nd Special Issue on Covid 19 Challenges January 2022

The Effects of Writing in a Class Blog on Saudi EFL Students' Attitudes

Alenezi

\section{Introduction}

Due to the introduction of the internet, which provided a wide choice of innovative online tools and applications for learning a foreign language in recent years, technology has advanced dramatically (Kazhan, Hamaniuk, , Amelina, Tarasenko, \& Tolmachev, 2020). Surely, everything with digital technology development has been quickly changed around us. These new technologies reduced the distances between the people making the farthest distance is the nearest one as these technologies no longer recognized any place and time borders since the appearance of the internet in the world of humanity. Undeniably, the latest Information and Communication Technologies (ICTs) significantly affected the minor details in our lives. The education sector also witnessed many learning opportunities due to the massive spread of technology which has contributed to providing a lot of benefits for learners and teachers and the most important of which is the benefits of Web 2.0 technologies in foreign and second language classes (Arslan, 2018; Dixon \& Thanyawatpokin, 2018; Hurlburt, 2008). Among these technologies that became famous ones in educational contexts around the world is a blog that can serve as e-learning for the whole class to make the students interact to help each other is based on the idea of sociocultural theory by Vygotsky's of social interactional learning. According to Campbell (2003), blogs are like an electronic forum by teachers and students to express their views, discuss ideas, and exchange information of interest. Therefore, this study tries to look into the usefulness of the class blog on the learners' writing. According to Campbell (2003), educational blogs have been divided into three types: tutor blogs used by the course tutor, learner blogs updated by the learner, and class blogs that are used by the whole class.

In Saudi Arabia, it is widely known that education is dominated by the teacher where the students in the learning process in the Saudi context remain passive all the time without any active interaction in contrary to education that adopts new technology. Notably, writing teaching, which is considered the greatest skill to master in Saudi Arabia, most of the Saudi students found it difficult and demanding tasks. Because the methods in which the students learn writing in English are ancient and impractical. As a result, this study aims to investigate the Saudi EFL learners' perceptions towards EFL writing teaching and learning through the use of the class blog as an innovative method in EFL writing classrooms. Campbell (2004) claims that using blogs enables students to access English websites and improves students' knowledge about the English language by allowing them to express themselves throughout interactions. As a result, the use of a blog in this study is inspired by Vygotsky's social constructivist theory (1978). Learning through social interaction among learners and their peers, according to Vygotsky's theory, leads to meaningful learning in an interactive context. The research was conducted on a blackboard website.

The education in Saudi Arabia depended on learning from the teacher for long decades. This strategy, which was used in the educational system for a long time, put students in a passive position, where they did nothing except obey the teacher's instructions. Consequently, this way made the situation is tough for the student to interact with each other or learn from each other through social interaction The socio-cultural theory by Vygotsky emphasizes its importance to enhancing one's cognitive activity and learning and supports integrative Computer-Aided Language Learning (CALL). Additionally, the social interaction among the students has created an opportunity for the less proficient students to learn from their more proficient learners in socio-cultural in an authentic environment (Selwyn, 2011). Therefore, interactive technologies 
Arab World English Journal (AWEJ) 2nd Special Issue on Covid 19 Challenges January 2022

The Effects of Writing in a Class Blog on Saudi EFL Students' Attitudes

Alenezi

like a blog have the potential to create new learning styles that adopt interaction and self-learning and collaborative writing when learning writing which is the most challenging skill. So, this study can bring many valuable benefits for learners and teachers interested in writing teaching in Saudi Arabia.

\section{Research questions}

The study aims to answer the following research question:

How do the Saudi EFL students perceive the effect of implementing a class blog in EFL writing classes?

\section{Related previous studies}

Multiple studies have been conducted on utilizing a blog as a learning tool from several perspectives. Many authors from all around the world have studied the usefulness of blogging and have published their findings on this novel technique. For instance, In the Turkish context, Icecap and Genç (2014) researched the effect of self-blogging on the writing skills of EFL Turkish learners and their perceptions toward their experiences with the blog. The study involved Advanced 13 Turkish EFL students enrolled in an English Composition Course at an Englishmedium institution in Turkey who participated in the study. The participants were juniors at the Faculty of Education, majoring in English language teaching.

The participants' average age was 19 years old. Throughout the 14-week study, each participant was expected to develop a learner blog in which they could complete their weekly writing tasks provided by their teacher and comment on their classmates' work. Paragraphs and essays on diverse topics were among the writing assignments. The information was gathered utilizing a mixed-methods strategy that combined a quantitative approach with the self-efficacy scale and a qualitative approach with semi-structured interviews. The findings discovered that the use of blogs had improved students' reflection, monitoring skills and writing skills.

Additionally, the students' writing self-efficacy improved as a result of peer criticism on their drafts acquired via the blog. In light of these findings, the author suggests that blogging be used as a practical exercise in writing classrooms to assist students to acquire metalinguistic awareness rather than writing self-efficacy. For the following reasons, the researcher found this study to be inspiring: (1). The research was carried out on EFL majors in the English language department at the undergraduate level. (2). It used a Mixed Methods research design by combining quantitative and qualitative research approaches. (3). It relatively implemented similar procedures to complete writing tasks (i.e., writing a blog and sharing blog.) However, the sample was minimal and its results cannot be generalizable to other contexts.

Similarly, Tekinarslan (2008) examined the experiences of a teacher and two groups of his undergraduate students at Turkey's Abant Izzet Baysal University, who used blogs to enhance their teaching-learning environment. Participants in both groups were enrolled in Computer Usage II, an elective subject. During the Spring semester of 2006-2007, the course was given at the same university's Faculty of Education. The students in the course learned a variety of programs, including database management in MS Access, fundamental web design applications in MS FrontPage, and Web 2.0 technologies such as blogs and wikis, throughout twelve weeks of instruction, since each software was scheduled for four weeks. Because blog tasks account for 
Arab World English Journal (AWEJ) 2nd Special Issue on Covid 19 Challenges January 2022

$20 \%$ of the total course mark, the course was given a score of 100 . The study involved 55 students ( 30 males and 25 females) and was divided into two groups studying in the third and fourth year in the elementary education department. Additionally, the level of English of the participants was limited. The participants were required to create their blogs via the learning management system: Blackboard to complete their writing tasks set by their teacher who was observing their works on the blog and recoding notes about their writing performance in the blog. The data were collected from observation, analysis of blog documents, and interviews with the participants.

The findings demonstrated that blogs were effective tools for publishing on the internet, meaning that blogs helped students improve their writing skills in terms of organization, paraphrasing, and citing their work. However, the researcher encountered two challenges while conducting his research: the first was limited access to the internet for most students outside of the university campus, and the second was students' ignorance of copyright issues when they copied and pasted from online sources and posted them as their own work in their blogs. Tekinarslan opened the path for a subsequent study about the crucial role that blogs can play in EFL classes to strengthen learners' writing skills, although his findings on the use of blogs among EFL learners were not very novel.

In the Arab world, Zarei and Al-Shboul (2013) carried out a study on a group of Saudi EFL learners to explore their perceptions on language learning through the blog in the Arab culture. They needed to check if blogging could assist students in improving their English skills. Ten postgraduate Saudi EFL learners enrolled in an English Intensive Course took part in the study. The study took place at Utara University in Malaysia for one semester. The study's participants were chosen at random manner. The information was gathered through semi-structured interviews with 10 Saudi postgraduate students who took part in the study and provided feedback on the use of a blog as a learning tool in an EFL course.

The findings discovered that learners viewed that the blog served as a supportive learning tool for them as it created a state of interaction that led them to exchange their experiences and ideas via the blog and this significantly contributed to improving their language skills and their feedback alike. Additionally, the study concluded that integrating a tool like a blog into EFL classes in Jordan could enhance their English language learning skills. However, can be criticized for being has several limitations like, firstly, being investigated the perceptions of the Saudi perception towards using blogs in EFL language learning without applying the blog as a practical intervention in their English course.

However, alternatively, it depended on the previous experience of learners using the blog. Second, this study was a small-scale study that relied solely on interviews to explore Saudi students' attitudes toward using blogs in EFL writing classes. Consequently, its findings cannot be generalized but it can be a preliminary study to help prospective researchers in this area.

In Palestine, Almudallal (2013) examined the effect of using the blog as a pedagogical tool supportive of the process writing approach on enhancing Palestinian students' English writing performance and improving their attitudes towards writing in English. The study involved 40 Palestinian EFL female students studying at Dallal Almughrabi secondary school in Gaza. They 
used a quasi-experimental approach by dividing the participants into two equal groups: a control group (20 students), and an experimental one (20 students). In terms of age, previous educational experience, and degree of English language proficiency in general, English writing skill in particular, and usage of writing processes, the students in both groups were equivalent. The experimental group's students used the blog as a learning tool to aid them in the writing process for the second term's writing tasks in the English for Palestine 11 course. The students in the control group, on the other hand, were taught writing using the traditional technique, which concentrated on giving students practice in writing without emphasizing writing processes or the usage of a blog. Three tools, a writing attitude scale, a process writing questionnaire, and a writing achievement exam, were used to collect data.

The results revealed that the mean scores earned by students in the experimental group who used the blog compared to their counterparts in the control group in the post writing achievement test were statistically significant. As a result, the experimental group's performance in English writing was significantly improved when compared to the control group's students. Furthermore, the data revealed that there were statistically significant changes in mean scores between the experimental and control groups during the questionnaire drafting process, favoring the experimental group. This study indicated the impact of using a blog in the writing classroom, as seen by a statistically significant increase in students' usage of writing processes as a result of using a blog in the writing classroom.

Furthermore, the data revealed that the participants had a good attitude toward writing in English after working on the blog as part of their writing activities. In light of these findings, the author advocated for the use of blogs in teaching English writing to improve students' English writing performance by enabling them to employ writing processes and create positive attitudes toward English writing. However, this study relied on a quantitative strategy to present its findings, which was insufficient to comprehend the research problem, ignoring the qualitative approach, which can help the quantitative approach to better comprehend the study's problem. Furthermore, this study differed from mine in that it used a quasi-experimental approach in which two groups, the experimental and control groups, were compared to a sample of female students.

However, this study was inspiring for me because it was conducted on a sample that was similar in terms of linguistic and cultural background to my study sample regardless of the sex of the participants. Additionally, it adopted writing processes that were integrated into the blog to teach the writing course that my study adopts.

Alamri (2010) conducted a study in Oman with 66 Omani students, both male, and female, to evaluate the role of the blog and Facebook as examples of web 2.0 apps in strengthening students' EFL writing skills. The participants in the study were divided into two groups (28 males and 38 females) who were doing their third, fourth, and fifth years of study in the College of Arts and Social Sciences and College of Education at Qaboos University participated in the study. Data were collected by employing a questionnaire, as well as verbal data (questions/interviews), which were used to obtain the required data which can answer the research questions. The researcher used the descriptive method to analyze the collected data. 
Arab World English Journal (AWEJ) 2nd Special Issue on Covid 19 Challenges January 2022

The Effects of Writing in a Class Blog on Saudi EFL Students' Attitudes

Alenezi

The findings elicited from the questionnaire discovered that the use of Facebook and blogs led to improving their academic writing proficiency, grammar proficiency, and fluency. Additionally, the findings indicated that students showed positive attitudes towards using Blogs and Facebook in improving their academic writing proficiency. Additionally, verbal data discovered that blogs and Facebook were good learning tools, and they were practical and interesting for the learners and easy to be used. Additionally, these tools enhanced cooperation, interaction, and communication between students. Although no major results about the use of blogs among Arabic learners were discovered in this study, Alamri presented an excellent historical perspective on educational blogs in EFL writing classes, which may pave the way for future research in the Arab world.

In Pakistan, Farook, Fatima and Javid, (2015) conducted another study in Pakistan on a group of twenty Pakistani undergraduate English language learners who were classified as EFL learners. The goal of the study was to see if using blogs in writing teaching can help Pakistani English learners improve their writing skills. The study lasted for six months as the students throughout this period were involved in writing activities. The participants in this project were required to do assigned writing tasks included paragraph writing, essay writing, and story writing to measure the development of their writing skills through their participation in these writing tasks in the blog. The data were collected through using the pre and post-test approach to assess the development of writing drafts in terms of structure, creativity, and logical sequence of ideas. The findings after the students' drafts were analysed found that using the blog improved the writing skills of the Pakistani learners of English, and as well as created a collaborative learning environment that enhanced participation and collaboration among learners that contributed to facilitating the learners to complete the EFL writing tasks. This study is similar to mine in that it was done in EFL writing classes and focused on a single set of EFL majoring undergraduate students. However, it differed from my research in that it took a quantitative approach, focusing solely on before and post-test models to assess students' writing performance over time. Furthermore, it appeared to me that it took twice as long to complete as my study. Furthermore, because the study did not thoroughly investigate the study topic and did not examine the phenomena in detail, as well as the sample size, being small, the conclusions of this study may not be reliable to be transferred to other contexts. Lee (2020) conducted a study to explore the effectiveness of blogging in improving the L2 writing skills of learners. The student involved 48 students who used blogging foe ding their writing assignments. L2 learners were required to use blogs for doing their writing tasks. The finding discovered that blogging was an effective tool for improving the learners' writing skills. Sanjaya, Apriani and Edy(2020) examined the perceptions of a group of Indonesian students about the effects of using a blog in EFL writing studying English as a foreign language (EFL) to improve their writing skills. The study involved 30 students who practiced writing by blogging. The students after the invention was over, were given a questionnaire which was the only tool of data collection to express their perceptions about the effect of blogging in their EFL writing classes. The findings demonstrated that the majority of the students have a positive perception of the effectiveness of using blogs in EFL writing classes to improve their writing skills. Yousefifard and Fathi(2021) examined the effect of blogging in EFL writing classes. The study involved 47 Iranian EFL learners who were studying in a private institute. The students in the study were divided into two groups: experimental and controlled groups. The experimental group was taught writing by using blogging while the controlled group was taught writing by traditional method in the class 
Arab World English Journal (AWEJ) 2nd Special Issue on Covid 19 Challenges January 2022

throughout twelve weeks. The results demonstrated that using blogging in EFL writing classes was effective in developing the writing skills of EFL learners.

Finally, Alhojailan (2012) did an action study to determine the efficacy of blogging among Saudi university students. His research included 30 students that were enrolled in the class. Questionnaires and interviews were used to collect data for the study, which was done qualitatively. The findings demonstrated that the participants in two groups had opposing viewpoints on how to use the blog. The first group of participants stated that blogging was not as effective as they had hoped. The other students in the second group, on the other hand, expressed their satisfaction with the effectiveness of using blogs to improve their learning experiences.

\section{Method}

As stated earlier, the objective of this study is to investigate the Saudi EFL Learners' perceptions towards EFL writing learning through implementation of blogging as an innovative approach in the EFL writing classrooms. This study employed a qualitative method approach to collect data using semi-structured interview which is defined as a direct conversation between a researcher and an informant, or groups of informants, resulting in valuable information" (Nunan, 1989, p.60). According to Patton (1990), interviews can give a better opportunity to understand the complex behavior of participants in a study. As a result, it is considered a valuable tool for data collection in in-depth studies. So, it is employed in this study to collect more details about the experiences of the Saudi EFL learners and their attitudes and perceptions toward writing by blogging.

\section{Participants}

This qualitative case study involved five undergraduate Saudi EFL Learners who completed a compulsory English writing Course (Academic writing skills) for one semester at the Department of English at the university in the year 2020. The participants agreed to take part in the study to learn more about their experiences with the blogging as a unique form of innovative web2.0 technologies amid of the spread of pandemic Coronavirus and heavy procedures from the university to keep the students safe. The study was conducted in the first semester of the academic year of 2020 and lasted for three months with integrating blogging in their writing course to do their writing tasks. The course was preceded by an introduction to writing course. The course was credited two hours per class and a total of two sessions per week. The study used a class blog which can be considered as an e-forum through linking the students' blogs to the class blog and the teacher blog to make the students interact and discuss their issues which each other (Campell,2003). The students through the blog were required to write their drafts and publish them for review from their peers and their teacher and exchange the comments between the same class members and their teacher via class blog.

\section{Research design}

This case study is an exploratory study adopting a qualitative approach. it was conducted in the Department of English Language by interviewing 5 undergraduate students after they were involved in writing activities using a blog for one semester to discover their perceptions and their attitudes toward their experience with blogging and how they found it. The semi-structured interviews were the only tool to collect data in this small exploratory case study to explore the perceptions of Saudi learners toward their integrating blogs in their writing curriculum. The 
Arab World English Journal (AWEJ) 2nd Special Issue on Covid 19 Challenges January 2022

The Effects of Writing in a Class Blog on Saudi EFL Students' Attitudes

Alenezi

interviews were conducted with the willing participants after they finished their course with blogging.

\section{Procedures}

Firstly, the writing tasks were prepared to be done by the class members using blogging. Secondly, the tool of data collection was piloted to guarantee that the questions are legitimate and dependable by handing them to three educational research specialists. The three experts determined that the interview questions were valid and dependable enough to be used as the primary method to achieve the study's objectives after making some adjustments to the questions. Following the pilot study, several of the questions were updated and improved based on feedback from the students. The final version of the semi-structured interview questions was used to collect data for this study. Thirdly, to avoid any bias against the participants, the gatekeeper (i.e., ELT teachers) who were teaching in the same Department that the researcher was working for were not directly or indirectly involved in teaching the students interviewed all of the student participants using the English club in the same Department. Fourthly, the qualitative data obtained from the semi-structured interview were recorded, translated into English after they were done by the learner's native language namely Arabic, and then transcribed to discover the themes and subthemes that can achieve the objective of this study of understating the perceptions of the Saudi learners towards using the blog in their writing course. Finally, the data were analyzed and coded using thematic analysis based on Braun and Clarke's procedures of thematic analysis.

\section{Findings}

This study, as stated earlier, focused on investigating the Saudi EFL learners' perceptions towards EFL writing through the interactive class blog. The data were collected and analyzed based on the goal that guided this study. Five Saudi EFL learners were involved in this study to discuss their experiences with blogging when they were involved in a compulsory writing course. Many questions were asked of the students throughout the interviews in order to better grasp some of the challenges surrounding their blogging experience

The first question in the interview was designed to elicit their thoughts on EFL writing learning through a three-month-long blog. All of the students $(n=5)$ said that learning EFL writing through the blog was a fun and rewarding experience and that it helped them improve their writing and reading skills by broadening their English vocabulary and grammar.

Although, they confirmed the difficulty of using the blog for the first time, for example, one of the interviewees mentioned that:

\section{Student A}

I enjoyed the idea of using the blog in writing classes, although I faced some difficulties to deal with the blog in the first stages as it was the first time I use it. However, after I published the first post, I found that it is a great method to practice writing by interacting with my class members.

On the other hand, only two of the learners claimed that they were using the traditional method that adopts pen and paper with assistance from the teacher for a long time so, they did not find using a blog was motivating for them. For example, one of them stated: 
Arab World English Journal (AWEJ) 2nd Special Issue on Covid 19 Challenges January 2022

The Effects of Writing in a Class Blog on Saudi EFL Students' Attitudes

Alenezi

\section{Student B}

I cannot use blog technology from the first time as I was involved for a long time in learning through using the pen and paper method and following the explaining and guidance from the teacher, so I cannot consider this tool as a practical tool for me but maybe in the future, my views will be changed if I kept using blog.

The second question was asked to find out how their writing skills improved through blogging. All learners mentioned that blogging made them deal with vocabulary and grammar and structure issues when they post on the blog or read other students' posts in the blog. Consequently, this frequent process in the blog increased their vocabulary and contributed to reducing their grammar errors in their writing tasks through their interaction with their peers. For instance, one student stated the following:

\section{Student A}

I think that practicing writing in the blog opens the space in front of you to learn from the experience of others especially, in terms of developing vocabulary and sentence structures issues". As using a blog provided a lot of help in doing the writing assignment that my teacher asks me to submit on time.

The third question of the interview was asked to the students to know the essential benefits they found when they were involved in writing on the blog. Based on the learners' respondents, the students mentioned many benefits of using the blog. However, most of the students agreed that interaction with their teacher and their peers in the class provided them with very constructive feedback in "cyberspace" which has contributed to correcting many of their writing mistakes. For example, one of the learners mentioned the following:

\section{Student B}

In the past, I was doing my assignment individually at home and there is no other tool to ask and find answers for the questions that remained unanswered. Unfortunately, I find myself doing my assignment in any form, as the only thing I focus on submitting is on time regardless of wrong or right, but with the blog, I found a very important interactive and motivating environment. I when I face some difficulty with something, I only post my question in the blog comment box and a few minutes I receive many answers from peers and sometimes from the teacher and this facilitates my learning and I feel comfortable and that my learning is meaningful. Additionally, when I publish some writing drafts, I received a lot of feedback from my peers and my teacher, and automatically, this feedback moves to be constructive discussion, it is a fantastic tool for developing writing.

The fourth question was asked to explore the challenges and challenges that learners faced when writing a blog. In this issue, the learners mentioned many challenges facing them. However, nearly All most with no exception agreed that the most severe challenges they faced while using blogs were frequent internet connection issues and time-consuming and unfamiliarity with the blog. For example, one of the interviewees stated the following:

\section{Student C}

I used to blog in the first stages with fear and while I was practicing my writing on the blog I loved blogging as a constructive method of learning writing. However, I face the 
Arab World English Journal (AWEJ) 2nd Special Issue on Covid 19 Challenges January 2022

The Effects of Writing in a Class Blog on Saudi EFL Students' Attitudes

Alenezi

problem of poor internet connection which made me unable to continue to practice writing. Additionally, the blog consumed a lot of time as I have busy loads of works.

\section{Student D}

Unfortunately, I was not interested in the computer, and I do not use it, consequently, I have experience in using technology including the use of a blog that the first time I hear about this study. My poor technology skills affected directly in using the blog.

The fifth question was asked to understand if the learners plan to use the blog or not in the future after their course-integrated blog is concluded. The students according to their responses in the interviews indicated that they would continue to use the blog in the future even if the study finished to the degree that some of them will recommend others to use the blog. For example, one of the interviewee students indicated that

\section{Student $E$}

The blog helped me to improve my writing skills and contributed to increasing his vocabulary in English through the valuable interaction with others in the class, so I will never stop using the blog even after the class finishes, and I will continue using the blog in writing activities practice and I will recommend it for the other people to use it in developing their writing.

\section{Discussion}

The results of the study demonstrated that the use of blogging was an effective approach in EFL writing classes. Additionally, the results of this study showed that the perceptions and attitudes of the Saudi learners were positive towards writing using blogging. These results aligned with results of many previous studies in this area that investigated the effect of implementing blogging in EFL writing classes. For example, Alhojailan(2012) examined the effect of using blogging in their learning. The findings discovered that the students expressed their positive attitudes towards using blogs to improve their learning experiences, indicating that the use of blogs was an effective tool in their learning process. Additionally, Farook et al.(2015), who examined the impact of the use of the blog in the EFL writing classes among Pakistani learners. The study showed the effectiveness of the use of blogging in the EFL writing classes and the attitudes of the learners were positive toward using blogging in their EFL writing. Additionally, a recent study by Yousefifard and Fathi(2021) examined the effect of blogging in EFL writing classes. The study involved 47 EFL Iranian learners who were studying in a private institute in Iran. The results demonstrated that using blogging in EFL writing classes was effective to develop the writing skills of EFL learners. These studies suggest that implementing blogging in EFL writing classes was effective and the attitudes of the learners were positive. Additionally, a study by Almudallal (2013) when she examined the effect of blogging on Palestinian learners. She found the performance of learners who practiced writing by blogging was better than their colleagues who practiced writing by the traditional method that was limited to the class borders. Consequently, the results of the previous suggest the effectiveness of blogging in EFL classes and on the learners' attitudes toward writing. Accordingly, my study results came consistent with the results of these previous studies. 


\section{Conclusion}

The study aimed to explore the attitudes of Saudi EFL learners towards writing in the class blog. The study found the integration of blogs into their writing course was effective toward writing blogging. It also, seemed that their experience and their attitudes with using a blog in their EFL writing course were positive according to their feedback in the interview. They all agreed that the blog gave them an open forum to communicate, connect, and discuss with their classmates and teacher. As a result of the interaction established by the blog and the process of exchanging feedback among the learners, they perceive the blog as a valuable learning tool and a unique experience that helped them enhance their EFL writing skills.

\section{Limitation of the study}

- The sample population for this case study consisted of a small group of undergraduate students at Saudi University, therefore, cannot be generalized to a larger population.

- This study depended on one research method namely interviews to collect data collection. Consequently, this can be a shortcoming, as the recommendation in this issue is that more research methods be used to collect data to guarantee that we have valid and reliable data.

\section{Recommendation and suggestions}

This small case study was conducted with five students to explore the Saudi perceptions towards the use of blogs in their writing classes. According to the aim and results of this study, the following recommendation and suggestions are made:

- It is suggested that this study be duplicated with a large group of students

- More qualitative studies are recommended to be conducted to investigate the effects of using the blog in more depth as well.

- It is recommended that more qualitative methods like diaries, observation, interviews, etc. be employed in future studies that are prepared to investigate the effect of using the blog in writing classes.

- It is recommended that the blog software be included in the writing courses as the practical part of the course.

- It suggested that more qualitative done to investigate the use of blogs in other courses such as speaking, listening, and reading

- It is suggested that other studies were conducted to investigate the performance of the EFL learners through blog technology with employing the pre and post-test to measure the achievement of the students with using the blog.

\section{About the author}

Sultan Samah A Alenezi: Lecturer of Translation studies and Applied Linguistics. Department of English and Literature-University of Northern Border -Saudi Arabia. He is interested in Translation pedagogy, lexicography, academic writing, interactive technologies, particularly blogging in EFL writing classes. He is doing his $\mathrm{PhD}$ in the university of Limerick in Ireland about implementing of blogging in EFL writing classes. https://orcid.org/0000-0002-5312-7289. 
Arab World English Journal (AWEJ) 2nd Special Issue on Covid 19 Challenges January 2022

The Effects of Writing in a Class Blog on Saudi EFL Students' Attitudes

Alenezi

\section{References}

AlAamri, K. (2010). Using web 2.0 technologies to enhance academic writing proficiency among ESL students in Sultan Qaboos University: An example of Facebook and blogs. A paper presented at the International Conference on the Future of Education, Florence, Italy.

Alhojailan, M. (2012). The current use and effectiveness of Weblogs as e-learning tools in higher education. 3rd International Conference on e-Education, e-Business, e-Management and e-Learning, Singapore, IACSIT Press.

AL-Mudallal, I. (2013). The Effect of Using Weblog on Enhancing Palestinian Eleventh Graders' English Writing Performance and their Attitudes towards Writing. MA dissertation. Gaza University. Palestine.

Arslan, S. (2018). A review on the delivery of the professional development programs for EFL teachers: Face-to-face, online and blended programs. Turkish Studies Educational Sciences, 13(27), 97-106.

Braun, V. and Clarke, V. (2006). Using thematic analysis in psychology, Qualitative Research in Psychology, 3(2), 77-101.

Campbell, A. P. (2003). Weblogs for Use with ESL Classes. The Internet TESL Journal, 9(2), 33-35.

Campbell, A. P. (2004). Using live journal for authentic communication in EFL classes. The Internet TESL Journal, 10 (9), 51-62.

Dizon, G., \& Thanyawatpokin, B. (2018). Web 2.0 tools in the EFL classroom: Comparing the effects of Facebook and blogs on L2 writing and interaction. The EUROCALL Review, 26(1), 29-42.

Farooq, M. U., Fatima, Y., \& Javid, C. Z. (2015). Enhancing writing skills through blogs in an undergraduate English language classroom in Pakistan. Linguistics and Literature Review (LLR), 1(2), 105-118.

Hurlburt, S. (2008). Defining tools for a new learning space: Writing and reading class blogs. MERLOT Journal of Online Learning and Teaching, 4(2), 182-189.

İnceçay, G., \& Genç, E. (2014). University Level EFL Students' Self Blogging to Enhance Writing Efficacy. Procedia - Social and Behavioral Sciences, 116, 2640-2644.

Kazhan Yu M, Hamaniuk V A, Amelina S M, Tarasenko R O and Tolmachev, S. T. (2020). The use of mobile applications and Web 2.0 interactive tools for students' German-language lexical competence improvement CEUR Workshop Proceedings 2643 392-415.

Lee, L. (2020). An exploratory study of using personal blogs for L2 writing in fully online language courses. In Recent Developments in Technology-Enhanced and ComputerAssisted Language Learning (pp. 145-163). IGI Global. https://doi.org/10.4018/978-17998-1282-1.ch007

Nunan, D. (1989). Understanding language classroom: A guide for teacher-initiated action. London: Prentice-Hall.

Patton, M. Q. (1990). Qualitative evaluation and research methods (2nd ed.). Newbury, CA: Sage.

Sanjaya, H. K., Apriani, E., \& Edy, S. (2020). Using web blogs in teaching writing for EFL students. Journal of English Education and Teaching (JEET), 4(4), 516-535.

Selwyn, N. (2011). Education and technology: Key issues and debates. London:Continuum.

Tekinarslan, E. (2008). Blogs: A qualitative investigation into an instructor and undergraduate students' experiences. Australasian Journal of Educational Technology, 24(4),402-412. 
Arab World English Journal (AWEJ) 2nd Special Issue on Covid 19 Challenges January 2022

Vygotsky, L. L. S. (1978). Mind in Society: The Development of Higher Psychological Processes. Cambridge: Harvard University Press.

Yousefifard, S., \& Fathi, J. (2021). Exploring the impact of blogging in English classrooms: Focus on the ideal writing self of EFL learners. International Journal of Instruction, 14(4), 913-932. https://doi.org/10.29333/iji.2021.14452a

Zarei, N., \& Al-Shboul, Y. (2013). Participating in a blog: Jordanian EFL learners' voices. English Linguistics Research, 2(2), 53-59. 